\title{
The Economic Consequences of the Political Crisis
}

\section{Ronan Porhel}

\section{(2) OpenEdition}

\section{Journals}

Electronic version

URL: https://journals.openedition.org/eastafrica/727

DOI: 10.4000/eastafrica.727

ISSN: 2790-1076

\section{Publisher}

IFRA - Institut Français de Recherche en Afrique

\section{Printed version}

Date of publication: 1 April 2008

Number of pages: 231-258

ISSN: 2071-7245

\section{Electronic reference}

Ronan Porhel, "The Economic Consequences of the Political Crisis", Les Cahiers d'Afrique de l'Est / The East African Review [Online], 38 | 2008, Online since 18 July 2019, connection on 09 December 2021. URL: http://journals.openedition.org/eastafrica/727 ; DOI: https://doi.org/10.4000/eastafrica.727

This text was automatically generated on 9 December 2021.

Les Cahiers d'Afrique de l'Est / The East African Review 


\title{
The Economic Consequences of the Political Crisis
}

\author{
Ronan Porhel
}

1 On the eve of the elections, the Kenyan economy was presented as the best performing in a region marked by armed conflicts (Ethiopia, Uganda, Somalia, Sudan or the Great Lakes region) and, thus sometimes experienced chaotic economic development. The political crisis led to the closure of factories, to the accumulation of delays in supplies, to cancellation after cancellation by tour operators in the tourism sector and even to the collapse of the stock market. The stage was thus set for impoverishment of the country but also the region, since Kenya is, for geographical reasons especially, the gateway for supplies to many landlocked countries in East and Central Africa.

2 Nevertheless, the Kenyan economy was going through a phase of growth, which began during President Mwai Kibaki's five-year term (2002-2007), both in terms of growth in industries and tourism. This clear recovery, facilitated by the resumption of funding by donors (particularly the International Monetary Fund and the World Bank), was a sign of reassuring stability for investors, which was beneficial for the region as a whole. This meant that the political crisis that Kenya was experiencing tarnished this image and potentially had economic consequences, in the short-term and the long-term, that could not be ignored, both for country and its neighbours.

\section{Years of great beneficial economic growth}

3 Since 2002 when M. Kibaki succeeded Daniel arap Moi, Kenya enjoyed a real improvement of its economic indicators. These indicators augured well for the future and strengthened its position as a regional leader.

\section{A promising economic and financial situation}

4 Kenya has a diversified ${ }^{1}$ industrial foundation and of a dynamic educated middle class. It is for this reason the logistical distribution hub (sea port and airport) of East Africa, 
whose market it penetrates with ease. Finally, Nairobi is a relatively robust financial centre at the level of the whole African continent.

5 Since 1993, the country opted for a market economy which is more open to the outside world, abandoning strategies based on import substitution. Whereas the tools of essential control of balance of payments and protection of its local industry depended on government controls (and especially the use of licenses), ${ }^{2}$ the main instrument of commercial politics in Kenya therefore became its common external tariff in line with GATT followed by $\mathrm{WTO}^{3}$ prescriptions, which should adjusted downwards within the East African Community (EAC). ${ }^{4}$

6 From the economic point of view, the Kibaki government achievements seem positive. The country resumed a path of growth that is more in conformity with a Developing Country (DC), with growth rates above $5 \%$. This is sharp contrast strongly with the end of D. arap Moi's rule when the rates revolved around zero per cent ${ }^{5}$. Moreover, Kenya is characterized by a constant increase in the standard of living indicator; its GDP per capita in parity with the purchasing power increased from 1,250 dollars in 2001 to 1,786 dollars in $2006^{6}$ ( 380 to 580 current dollars). Particularly worth noting is the fact that these results have been obtained with donor support of the about 1\% of GDP compared to about $10 \%$ donor support for neighbouring Tanzania. In this context, Kenya is cited as an example for the other African countries.

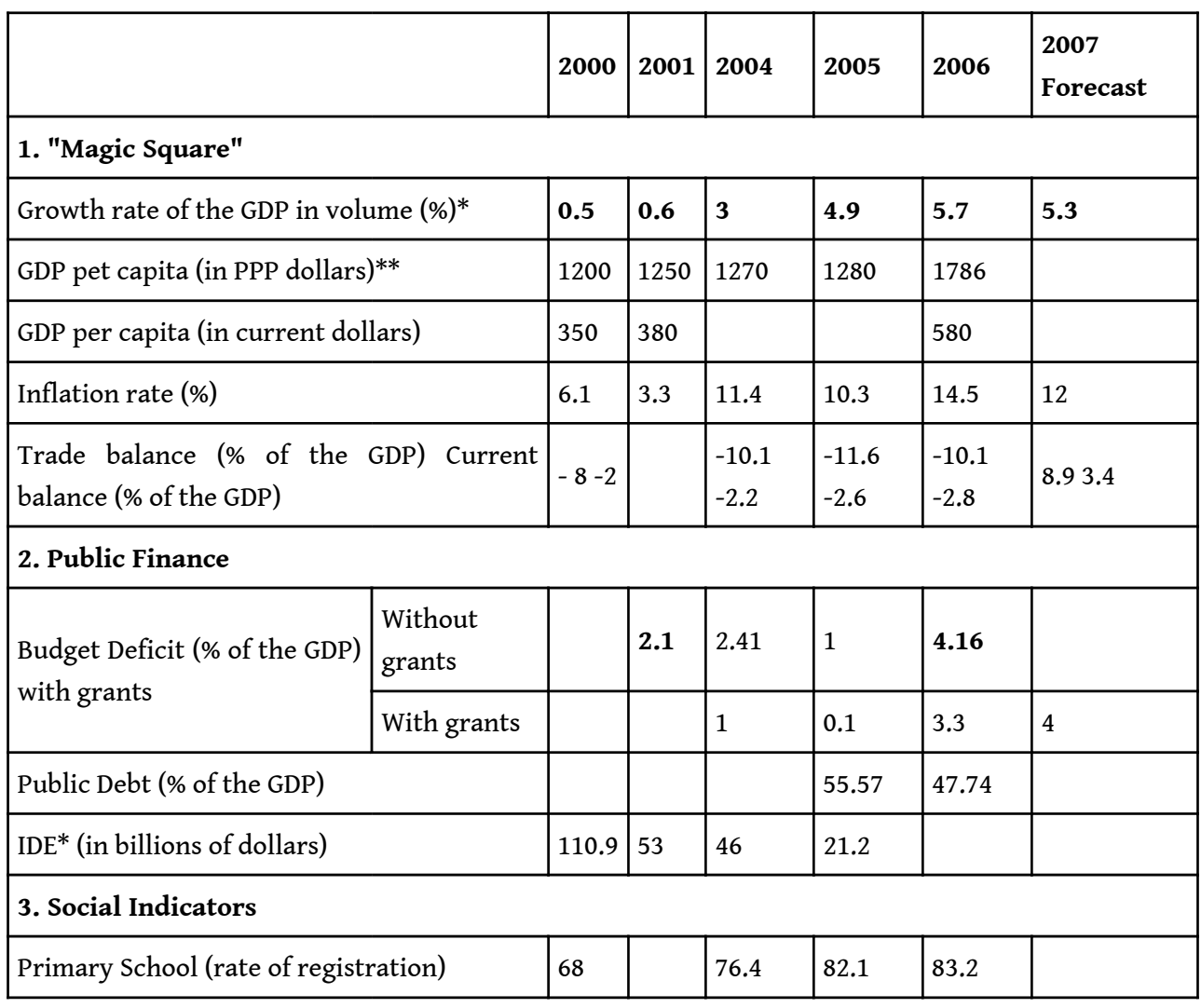




\begin{tabular}{|l|l|l|l|l|l|l|}
\hline Life Expectancy (in years) & 48.4 & & & 49 & & 55.3 \\
\hline
\end{tabular}

* In volume: the assessment of wealth produced is adjusted by inflation.

** Purchasing-Power Parity: The Purchasing-Power Parity (PPP) (means values measured in purchasing-power parity) is a method used in economics to establish in comparison with other countries the purchasing power of national currencies, which is cannot by simply using the exchange rates. The PPP makes it possible to measure how much a currency facilitates the purchase of goods and services in each of the zones compared.

7 The direct consequence of this economic growth is, however, the sinking of the commercial deficits. In 2006, the country had a deficit of nearly $9 \%$ of its $\mathrm{GDP}^{7}$ in spite of surplus in the balance of services (especially tourism) and two-digit inflation ( $14.5 \%$ in 2006). Paradoxically, this result, which was initially disappointing, was an expression the vigorous recovery of the Kenyan economy, which has to import all its oil. Finally, the last point about "Kaldor's magic square," 8 the unemployment rate quickly decreased. Even though it rose officially to $40 \%$, the amount of contribution by the informal sector, which is by definition unquantifiable, was so high that this figure lost its relevance. In Nairobi, for example, more than two out of three people work in the informal sector. ${ }^{9}$ Public finances remained sustainable in the eyes of the IMF in spite of the deteriorating situation, ${ }^{10}$ mainly due to funding for free primary school. The flow of foreign direct investment remained positive but was on a sharp decline ( $\$ 21$ billion in 2005 compared to over 100 billion in 2000) during M. Kibaki's term. This decline can be explained both by recovery by the closest neighbours, Tanzania and Uganda, which had regained political stability by adhering to economic liberalism, and by a certain tendency by the country be too risk-averse to open up to the foreign capital. In this connection, there has been significant change in legislation to address the situation, including the simplification of administrative procedures by creating a one-stop shop to process foreign investment applications. The value of foreign investment passed the US\$ 100,000 mark. Nevertheless, evidence revealed reticence over possible foreign take-over of Kenyan companies (a practice that did not impede Kenyan investors in Uganda and Tanzania in any way). The social situation remained fragile, ${ }^{11}$ however, with inequalities which were already high at the beginning of M. Kibaki's term (the country was ranked tenth on the world list of the countries with the highest level of inequality in terms of wealth) worsening and the Human Development Indicator (HDI) continuing to drop since $1990 .{ }^{12}$ It is true that when a poorly performing economy begins to grow very quickly, as was the case in Kenya, the inequalities become more pronounced. The growth, which was concentrated on the service industry, only benefited a part of the population, which was close to the president and those working in expanding sectors (banks, tourism firms and communication agencies), while the poorest classes experienced reduction in their purchasing power. Kenyan youth, who make up the majority of the population, felt particularly neglected, even though better education had given them hope of having a better life than their parents. In a country where life expectancy is 55 years, the persistent under-employment in this section of the population can only be troubling.

These favourable growth rates can be explained by contribution from some very dynamic sectors. They should help Kenya become, by 2030, a low-income to a mediumincome country (+ US $\$ 765$ per capita per year from 1995). ${ }^{13}$ The primary sector is one of these dynamic sectors. It accounts for $27.5 \%$ of the GDP ${ }^{14}$, and undertakes crucial activities which attract foreign exchange either through fishing, coffee, tea or even 
horticulture. For example, since 2005, Kenya is the first world exporter of black tea, which is the third source of foreign exchange for the economy. Tea production takes place in the Rift Valley, among other places. In the Kericho area, production has improved by $16 \%$ since 2001 (despite a decrease in 2006 due to drought), representing a growth of $41 \%$ in value owing to the rise in world prices. Another example of the most dynamic sectors in the last few years are horticultural crops, including about hundred products (fruits, vegetables, flowers), making the sector the country's fourth source of foreign exchange. Horticulture rose by $64 \%$ in 2007 thanks to high international demand and poor climatic conditions in Europe ${ }^{15}$. These products raked in close to 50 billion Kenyan Shillings (Kenya shillings) ${ }^{16}$, including $63 \%$ from cut flowers alone ${ }^{17}$. These products, exported virtually exclusively to Europe, account for $14 \%$ of the country's total exports, which is $25 \%$ of the European market. These crops are grown around Lake Naivasha, in Thika near Nairobi, in Kitengela, and also around Mount Kenya, Lake Nakuru and recently in the Rift Valley around Eldoret.

9 The secondary sector, which has more often than not a wait-and-see attitude and accounts for $17.6 \%$ of the GDP, has begun to rejuvenate, especially with the resurgence of companies in the agro-food industry. Big groups of companies have emerged like the Kenya Meat Commission, Mumias Sugar Company, Kenya Seed Company, or New Kenya Cooperation Creameries. However, there is hope, especially from the tertiary sector that represents now accounts for close to $55 \%$ of the GDP. It is dominated by tourist activities which are growing rapidly $(+10 \%$ in 2006 and second source of foreign exchange after the remittances from the Kenyans in the Diaspora ${ }^{18}$ ). Following the AlQaida attacks in Kenya in 1998 and $2002^{19}$, income from this sector had fallen to $€ 190$ million in 2002 and then rose to $€ 617$ million in 2006 (this triple growth is proof of real dynamism). The year 2007 was a record year with over a million tourists visiting and a $15.4 \%$ rise in profits. For their part, new information and communication technology (NICT), as well as banking ${ }^{20}$ and financial sectors experienced a remarkable boom. Mobile telephony, ${ }^{21}$ for example, grew rapidly with an average annual growth rate of $67 \%$ since 2001 and encouraging prospects with regard to investments dedicated to infrastructure. ${ }^{22}$ Moreover, the Nairobi Stock Exchange experienced growth of $280 \%$ in five years, which attests to the confidence of the business community, and enabled the Kenya Shilling (Ksh) to appreciate during the whole period strengthening against the dollar from Ksh 78.6 in 2002 to Ksh 63.35 in December 2007, an appreciation of nearly $20 \%$. Likewise, in the "country risk" ranking, according to Doing Business in 2008, Kenya rose from $82^{\text {nd }}$ to $72^{\text {nd }}$ position between 2006 and 2007 due to marked improvement in access to credit, which encouraged incorporation of companies at the same rate.

\section{A pole of regional stability}

10 In the East African region, Kenya is characterized by relative stability. Indeed, the country has never been in open conflict with its neighbours and acts as a rear base for refugees from the Somali and Sudanese wars. It has also set an example on several occasions as a peace facilitator, especially within IGAD. ${ }^{23}$ This intergovernmental authority consists of seven northeast African States and especially works towards the resolution of the crises in Sudan, Somalia and Ethiopia. 
11 Kenya, an economic leader in East Africa, is also an initiator of the regional integration process as a member of the EAC (East African Community) and of the Common Market for Eastern and Southern African States (COMESA) ${ }^{24}$ (34\% of intra-regional trade). It has contributed to the opening up of markets by lowering its common external tariff and exporting more than $42.6 \%$ of its products to Africa, close to $2 / 3$ of which goes to Uganda and Tanzania.

In this context, Kenya affirms its regional economic domination by controlling an important transit trade towards several landlocked countries in the region. This trade is equivalent to a quarter of Uganda's or Rwanda's GDP and a third of Burundi's GDP. This trade is in a number of basic essential commodities. ${ }^{25}$ The Kenyan regional platform offers a generally high level of infrastructure, road as well as sea port and airport. For example, the port of Mombasa is the inevitable transit point for the region's imports as well as exports and makes it possible to access a large part of eastern Africa (Uganda and the Great Lakes) ${ }^{26}$ via the use what is commonly known as "the northern corridor," which means combining road and rail to Kampala, complete with a Mombasa-Eldoret pipeline). ${ }^{27}$ Several Kenyan companies therefore assume the role of regional leaders like the Kenya Airways. As the region's dominant airline, it interconnects the whole of eastern and southern Africa in addition to big international destinations, even though financial difficulties have made its position relative for some years now.

\section{A crisis with multiple repercussions}

13 M. Kibaki's swearing-in to serve a second presidential term on 30 December 2007 triggered a period of high tension and violence. The political situation became very unstable. Economically, as Kenya suffered short-term large scale damage, the surrounding countries were also affected by the effects of this crisis, thus plunging East Africa into uncertainty.

The assessment of the effects of the January 2008 events in Kenya is very delicate. A certain historical perspective is evidently necessary to measure the consequences in precise terms; Finance Minister Amos Kimunya only talked about it recently. However, we can already pinpoint the main obstacles at the national then regional level.

\section{At national level}

Right from the start, the Kenyan crisis was characterized by an escalation of violence in several parts of the country: in western parts around Kisumu, in the Rift Valley and in some parts of Nairobi. One can consider as the very first victims the business people, who very quickly suffered slow business, at best, or at worst, a total disappearance of their merchandise. In the initial days, 184 stores were looted and $80 \%$ of SMEs were affected in Kisumu. ${ }^{28}$ Eldoret, which experienced remarkable growth these last few years and had the potential of overtaking Nakuru, its neighbouring big town in the Rift Valley, bore the full brunt of the crisis as well as the flight of workforce and investors. The effect on employment was disastrous (several thousands of jobs were lost in Kisumu and Eldoret). All regions were affected by a shortage of essential goods. Thus, the Turkana District (to the north of the country), which is situated in an arid area and depends on other provinces for food products, experienced a $200 \%$ inflation in the 
prices of fruits and vegetables due to deterioration of transportation, worsening the shortage of these products. In Kibera, the biggest slum in Nairobi, water and electricity were disconnected in the first week of the clashes and the Toi market, the main supply point for residents, was completely razed down by rioters. "There were 3000 traders here, and 3000 others depending on the market for their livelihood. If you count their families and the customers, 200,000 people were dependent on this place," explained the chairman of the association of traders at the market, Ezechiel Rema. ${ }^{29}$ Millions of shillings worth of food and clothes went up in smoke on the first Sunday when the results were announced after rioters fired the stalls belonging to members of the Kikuyu ethnic community, to which President M. Kibaki belongs. Farmers no longer had access to markets, to which their daily survival depends.

In the second week of the crisis (beginning 7 January), deterioration in the supply of oil products very quickly led to a crisis in all other sectors. Oil is indeed an input ${ }^{30}$ for most activities. Since the supply points were the towns that were the most exposed to the violence (Kericho, Bomet, Mumias, Kisii or Eldoret for example), general activity was observed to slow down and hardly felt the resumption of transportation in midJanuary. Let us look at the effects on sectors that were most exposed to the crisis: tourism, the milk industry, the agricultural sector, small enterprises and financial markets.

\section{Financial markets which bowed but did not plunge}

17 As soon as the Nairobi stock market opened on 2 January, the sales plunged and the Nairobi Stock Exchange (NSE) fell by 277 points, representing a loss of $5 \%$ value (about US\$ 629 million or Ksh 40 billion) of total stock capital (US\$ 12 billion), which revealed a loss of confidence by investors. The following day, dealing was suspended at mid-day when the twenty share index dipped to $5,015.50$ points whereas it had passed the 5300 points in the course December 2007. This fall affected small as well as major investors. ${ }^{31}$ Similarly, the Kenyan currency, which had appreciated during M. Kibaki's first term, was under siege on the market. It depreciated to depths close to $10 \%$ within a few days, plunging against the dollar from Ksh 62.68 on 24 December to Ksh 68.5 on 7 January. To reassure investors, and in spite of this decline in the main financial indicators, NSE Chairman Jimnah Mbaru tried to remain optimistic by maintaining that the targeted growth of $8 \%$ in the $2007 / 2008$ financial year was justified and went on to predict growth for the NSE index from 30 to $40 \%$ citing fast recovery from the damage and the redirection of efforts towards the devastated areas. Terry Ryan, independent economic adviser to the Central Bank of Kenya, was more conservative and anticipated by 10 January a reduction in the GDP growth rate of 4 to 5 points because of the sectors affected by the crisis. ${ }^{32}$ These sectors were indeed some of the most performing in the country's economy, namely agriculture, tourism and financial services $(31 \%$ of the GDP).

18 After the first month of crisis it could be said that its impact on the financial markets needed to be qualified. On the one hand, the Stock market stabilized around 5000 points for its main index in mid-February. In fact, the call by Citigroup for a certain strict adherence to economic fundamentals and the injection of funds by Finance Minister A. Kimunya, obtained in part from the privatization of Telkom, helped to maintain the market and the national currency under Ksh 70 to the US dollar. ${ }^{33}$ Thus, in spite of the rise in bad debts, pressure on the interest rates was not excessively high at 
0.5 points. ${ }^{34}$ This could have, however, contributed to the slow investment in an uncertain and especially more expensive environment. Capital inflow expected from financial transactions planned by the government faced fresh delay. This is what happened to the joint venture between Safaricom and Vodafone which still seemed deadlocked throughout February whereas the market awaited it to sustain the transactions. It could be assumed that the set of the privatization programs were also doomed to delay. The other big transaction which involved paying out $\$ 300$ million in international debentures in March 2008, in order to finance infrastructure programs, also was in danger of failing. Although the finance minister announced on 27 December that the country enjoyed a rather promising international rating $(\mathrm{B}+),{ }^{35}$ the current situation was a reverse, this was at least the point of view expressed by Betty Maina, chief executive of the Kenya Association of Manufacturers and of the chairman of the Corporate Council of Africa, ${ }^{36}$ Maurice Tempelsman. For its part, the Stephen Hayes group, which is among the largest American companies, ${ }^{37}$ called upon investors to withdraw from the country and opt for new steadier markets. So at the end of February the situation remained obviously fragile, in anticipation of a political resolution of the crisis. The agreement to share power in the coalition government signed on 28 February between re-elected President M. Kibaki and opposition leader Raila Odinga restored relative confidence in the markets, and the sale of Safaricom shares was thus planned to be held between 28 March and 23 April 2008, but it would be adventurous to think that a return to normalcy could be achieved quickly.

\section{A particularly affected tourism sector}

19 By 3 January, during the middle of the high tourist season in Kenya, a high number of flights from most of the English tour operators (the main "supplier," with 290,000 tourists per year), quickly followed by other countries (France, Italy, Netherlands, Germany and Portugal), caused an immediate loss estimated at about Ksh 4 billion and 120,000 jobs from the first week, including 20,000 for the hotel industry alone. ${ }^{38}$ Less than $25 \%$ of the forecasts seemed to be assured whereas the sector raked in US\$ 916.3 million in 2007. The airlines, including Kenya Airways, directly bore the brunt of the backlash. The national carrier anticipated a high fall in its turnover, and cancelled some flights at once, such as Mombasa-Johannesburg or Mombasa-London.

After the first fifteen days of the crisis, with the political stand-off still in suspense and political and social frustration taking an ethnic dimension, the sector, whose contribution is $15 \%$ to national wealth, found itself in a particularly precarious situation. The hotel occupancy in Mombasa remained lower than $80 \%{ }^{39}$ recorded the previous year where the rate of occupancy passed the $80 \%$ mark. The situation in Nairobi was hardly better as occupancy oscillated between 15 and $35 \%$. A loss of $78 \%$ of income for the first three months is to be expected at Ksh 5.5 billion per month out of a total of Ksh 65.4 billion in 2007 (a quarter loss in 2007), according to Ongong'a Achieng (Executive Director of Kenyan Tourism Board). The estimates for this first quarter were 314,995 people and the adjustments bring it to 27,000 or a reduction of $91.4 \%$. The cruise calendar which extends from January to April was also affected by the same degree of cancellations. Finally, the national parks recorded a reduction in the number of visitors. For example, the Tsavo-East National Park, which receives 700 visitors daily during this period, received 170 and lost two-thirds of the revenue..$^{40}$ These successive setbacks led to 250,000 job cuts in the tourism sector, a figure that could prove to be 
even higher. ${ }^{41}$ On the other hand, the fall in the number of visitors since December 2007 had a considerable impact not only on financial income, but also on a number of initiatives to conserve national parks and other protected areas run by the Kenya Wildlife Service (KWS). ${ }^{42}$ Yet, leaders remained optimistic and cited the examples of Morocco and Egypt. ${ }^{43}$ Under similar conditions, they were able to recover fast enough. The arrival of 175 tourists from Europe in mid-February and the arrival of the first cruise ship, the "Royal Star," at the Mombasa port were therefore considered the first sign of sector recovery. Following the signing of the agreement between M. Kibaki and R. Odinga, hotel reservations rose ahead of the Easter holidays. They were mostly made local tourists who took advantage of the low price policy, 30\% reduction, or even invitation from hotels to spend the holidays by the sea. Though this politics was a transitory measure while waiting for the return of foreign tourists, professionals, according to Kuldip Sondhi, director of the Mombasa and coast tourism association, were aware that Kenyans should contribute more to the sector's revenue in future. ${ }^{44}$

\section{An agricultural sector punished by disruption of transport}

Through its persistence, the crisis affected the agricultural sector in three ways. First of all, farms situated in the most risky districts in the north of the Rift Valley (such as Kericho, Bureti and Bomet), were been completely destroyed in the numerous arson attacks and looting associated with the clashes. Then, the inability by staff to commute to their places of work or, even more dramatic, the feeding of the high number of victims reduced activity. ${ }^{45}$ Finally, the rise in crime through activities of organized gangs contributed to worsening insecurity on the main roads. An example is the erection of road blocks on the Eldoret-Nairobi road via Nakuru. The sector could not withstand these three causes: $20 \%$ of the harvest in the north Rift, ${ }^{46}$ the country's bread basket, was destroyed and the land could not be prepared during the January rains due to the displacement of 20,000 families. While taking into account the forecasts to lower maize harvest by between 15 and 70\% (in southern Kenya), there were serious concerns over food supplies for 2008. ${ }^{47}$ During the first week of crisis, tea plantations ${ }^{48}$ were adversely affected whereas horticulture (apart from scores of farms in the north Rift) could more or less maintain its level of activity thanks to the social policies on some farms around Naivasha, ${ }^{49}$ which consisted providing on site accommodation for their employees. But very quickly the escalation of violence caught up with this sector, particularly on Sunday 27 January, ${ }^{50}$ and production suddenly collapsed. ${ }^{51}$ For the whole range of agricultural activities, it is the third phase of the impact that became delicate to manage, meaning the transportation of both the necessary inputs purchased for production (fuel, packing material, manure, etc.) and the distribution of the harvested crop. The tea plantations were able stock their produce initially but this strategy quickly became futile considering the length of the crisis. The farms, whatever their produce, were therefore forced to transport their produce under escort like in Naivasha, Nyahururu, Limuru, Kiambu or Athi River. This new constraint not only raised the cost of transportation with insurance premiums in sky-rocketing rise but also prolonged the delivery times within a given period (February, March) where the flower business achieved $40 \%$ of its turnover. Thus the tea sector, which could have received a boost in exportation from the depreciation of the national currency, incurred losses in several billions of shillings..$^{52}$ Milk production, which halved, ${ }^{53}$ experienced the same problems, bearing in mind that most of the resources were 
located in the Rift Valley. The prospects of resumption remained even fuzzier when demand shot up, especially from refugees, weakening some companies, including New KCC, which was fighting to regain some financial stability. Despite the losses estimated in billions of Kenya shillings, the Kenya Flower Council maintained that the sector copped quite well with the events, compared for example to the tourism sector, and could become even an interesting alternative for investment. European clients still expressed concern on Kenya's capacity to provide a steady and quality supply in the long term ${ }^{54}$ and threatened to turn more to the growing competition in Ethiopia. To this contrasting image Eldoret area harboured ambitions of becoming an important centre for horticulture but the chronic instability could new initiatives. The first Eldoret-Netherlands airlift via Nairobi in the second week of February could just make the town attractive once again.

\section{Small entreprises teetering on the brink of bankruptcy}

22 As a result of direct consequences of the crisis, the small enterprises sector was inevitably faced with defaulting in the repayment of micro-credit to financial institutions. The enterprises found it impossible to repay their loans, ${ }^{55}$ which according to Samuel Deya ${ }^{56}$ put these financial establishments in difficulty and to a lesser degree the banking sector. ${ }^{57}$ Anne Mutahi, chairperson of the Kenyan Association of Microcredit Institutions (AMFI) admitted that $80 \%$ of credit, on a portfolio of Ksh 25 billion, will be rescheduled but the micro-credit sector had resolved to write off 10 to $15 \%$, representing a loss of Ksh 4 billion. ${ }^{58}$ Sustaining the small enterprises is very vital for the Kenyan economy because they contribute to $18.4 \%$ of the wealth, and even $25 \%$ outside agriculture. They also represent $74.2 \%$ of employment for the most underprivileged areas. The areas in question are mostly the slums of Kibera and Mathare in Nairobi, Eldoret, Nakuru and Naivasha towns in the Rift Valley, Kisumu in Nyanza, Kakamega in Western Province and finally Mombasa in Coast Province. A mechanism of international aid was put in place in the course of January for cushion the most seriously affected cases but it could soon become insufficient.

For public coffers, this crisis from the very first week resulted in a daily loss of Ksh 2 billion (US\$ 31.45 million) in fiscal resources. ${ }^{59}$ However, we should add US\$200,000 in customs revenue coming from trade with Uganda. In the end, the State, which had a Ksh 109 billion budgetary deficit for 2007/2008 financial year, could foresee financial difficulties to implement its policies, for example funding free secondary education. The sharp decrease in fiscal revenue for the first quarter of 2008 due to disruption of industry, transport, tourism, banking and horticulture, reduced the government's room for manoeuvre when the situation required high levels of investment, and could force it to resort to internal and external borrowing. ${ }^{60}$ Moreover, though mediation led by Kofi Annan finally succeeded and managed to get the country out of political limbo, threats by donors to withdraw once again from the country did not go away after all. Thus, the European Union, which provided over $€ 290$ million (equivalent to Ksh 400 million) between 2002 and 2007 could freeze or at least reduce the new tranche of $€ 383$ million (US\$ 540 million) planned for the 2008-2013 period, leading to the cancellation in one stroke of many infrastructure projects. ${ }^{61}$ The World Bank, which funds 16 projects in Kenya to the tune of US\$ 919 million, as well as three infrastructure projects in the region to the tune of US\$260 million, also considered the possibility of reducing its contribution. 


\section{At regional level}

\section{Landlocked countries quickly crippled}

"When Kenya catches a cold, other countries (Uganda, Rwanda, Burundi) catch pneumonia" the Ugandan media observed..$^{62} \mathrm{~A}$ look at the political and economic situation, the Kenyan crisis had an immediate impact on economies of the landlocked countries (Uganda, Rwanda, Burundi), ${ }^{63}$ close to 100 million people depending on Kenya for the supply of essential products, or fuel items, including oil. Uganda proved to be very vulnerable. Right from 1 January, the country closed its border in Busia to keep out violence, stations of big oil companies (Shell, Caltex, Total, Mobil or Gapco) doubled the price of petrol per liter (from 2,400 to 6,000 Uganda Shillings), ${ }^{64}$ and increase the price of diesel by $10 \%$. Moreover, this shortage of fuel forced the country to suspend some internal flights. ${ }^{65}$ The inflation also affected the main products imported from Kenya, following the depletion of stocks in all shops in the city of Kampala. The price of some products, like soap, increased by $100 \%$.

Continued violence throughout January sustained by activities of armed youth groups, particularly along the Eldoret-Busia road, more or less paralyzed all the road as well as rail traffic along the northern corridor ${ }^{66}$ having a double effect of blocking the port of Mombasa and adversely affecting the intra-regional trade. Thus, the port facilities at the country's second largest city was incapable to manage the continuous flow of containers in spite of help from the port of Dar es Salaam, Tanzania, were quickly overrun. The peak was attained in January with 19,000 containers neglected on the quay of the Kenyan port, whose storage capacity is 7000 per day. The stock has reduced to 11,000 containers since February but remains excessive ${ }^{67}$ for the normalization of activity. In fact, the situation improved slightly since Ugandan Prime Minister Eriya Kategaya's visit to Kenya on 31 January, which ended with the first convoy of trucks escorted by the Kenyan army. However, only a third of the traffic is therefore assured out of the normal 1250 daily trucks, bearing in mind that the cost is raised for security reasons. ${ }^{68}$ Ugandan importers put the probability to receiving goods in good condition at $50 \%$. In this context, the northern corridor, which is already well-known for its administrative lethargy, operates in slow-motion and impacts heavily on the volume of trade. Concerning imports, the accumulated delay in the delivery of oil products, apart from the increase in prices, punish all downstream activity that must also to bear with deficiency in the supply of capital goods leading to a rise in technical unemployment and a decline in the turnover of some companies. It is, for example, the case of the Madhvani group of industries, whose forecast of 150,000 tons in its sugar sector transactions will not be possible to achieve due to lack of material. Of more concern, according to FAO, essential food products like cereals (wheat, corn, barley) already in insufficient quantities due to unfavourable climatic conditions, are beginning to miss and could trigger a period of food crisis worsened by the displacement of refugees. Exports involving perishable goods (coffee, tea, fish), or $30 \%$ of the GDP, are experiencing a decline whereas insurance companies refuse to take on the transportation charges. Only coffee industry managed to clear a surplus in December 2007 (326,466 bags of coffee compared to 237,168 bags). latest report on the impact of the Kenyan violence on the Ugandan economy ${ }^{69}$ Thus, on 
15 February, URA (Uganda Revenue Authority) spokesman Patrick Mukiibi put the scale of the crisis into perspective by revealing that the fiscal results had only marginally been achieved. The decrease is only US\$ 1.34 million on the estimated revenue (-1\%), thanks to better internal revenue that made it possible to compensate losses on the customs revenue of about $\$ 5.2$ million (-7\%). The January growth rate will nevertheless be the lowest in eight years but the rate of inflation, which has been boosted by the increase in prices of fuel could be quite low (the month of January was only be characterized by a further one point inflation) following the choice by industrialists to find other alternatives to road transport. Abe Selassie, the IMF permanent representative in Kampala, still maintained his confidence in the Ugandan economy to cope with this period in view of the proper observance "economic fundamental," but he recognizes that exposing the country to such risks should lead to review the supply sources and to invest in infrastructure. Some business quarters sought to remain confident while hoping for a redeployment of investments planned for

Kenya to other countries of the region but this point of view seems somewhat optimistic: the investors could very well move away from a region whose pole of stability, which hitherto has been Kenya, is experiencing a crisis a way out of which is still not known. The tourist sector is in this respect revealing: cancellations also occurred in Tanzania and Uganda.

\section{The need to find an alternative to the northern corridor}

The decision by Rwanda to import part of its energy from the port of Dar is Salaam since the oil shortage ${ }^{70}$, the example of the convoy of the United Nations High Commission for Refugees (UNHCR) transporting steel to Ajumani, Uganda, which was rerouted to Dar es Salaam during the crisis at a $20 \%$ surcharge and a longer distance that cannot be ignored which finally led to the dispatch of a Ugandan government delegation to the Tanzanian port ${ }^{71}$ on 4 February, to officially inspect port facilities, and at the same time unofficially apply pressure on the Kenyan government, reveal the extreme vulnerability of landlocked countries to the same northern corridor which already in normal times does not ensure efficient deadlines.

The crisis should at least make all the actors realize the need to find the way out the impasse, although the conditions are quite limiting. One way or another, this will happen through the acceleration and a concretization of regional infrastructure projects such as reinitiating the second corridor between Dar es Salaam in Kampala via Mwanza, and at the same time ensuring better flow of traffic. ${ }^{72}$ The first obstacle is releasing the millions of dollars needed for the extension of the pipeline, which now reaches Eldoret, to Kampala andto once and for all overcome the intra-Kenyan quarrels as well as political and financial interests. Secondly, there is need to modernize Tanzanian infrastructure, which are very from the standards of a new East African hub. ${ }^{73}$ The port of Dar is Salaam only handles 165,000 containers per year compared to the 300,000 by Mombasa $^{74}$ and requires a waiting period of two weeks. The state of roads does not allow transit of the heaviest trucks, which must use obsolete railway facilities. In comparison to the northern corridor, the central corridor currently implies a surcharge of US\$ 3000 to US $\$ 4000$ per container. Consequent investment is therefore indispensable to improve the port's productivity, to modernize the railway line as well as the road network. Finally, there is need to strengthen the fleet in order to transport the goods from Mwanza to Port Bell near Kampala. This ambitious challenge is not new 
but the emergency of the situation could enable the countries, for once, to overcome partisan interests.

\section{Conclusion}

The Kenyan political crisis, since the 27 December 2007 elections, upset the economic and social situation of the country and the region. Due to escalation of violence that cut means of communication, all the economic sectors incurred heavy losses, weakening their financial balance. Efforts by former UN Secretary-General K. Annan, as well as pressure from donors, to help negotiate an agreement between President M. Kibaki and his rival R. Odinga, do not mean that the country will quickly recover from the situation. At the national level, the finance minister officially revised the predicted growth rate of the GDP for 2008 by three points ( $5 \%$ instead of the predicted $8 \%$ ).

Moreover, poor weather conditions do not augur well for this year's production by agricultural sector. At the limit, the immediate announcements of fundamental reforms, redistribution measures in respect of underprivileged regions and those left out by the growth, will be necessary to slow down or stop the build-up of violence. According to Steven Smith, chairman of the Kenya Association of Manufacturers, there will be need for 12 to 18 months to recover the levels of activity achieved in 2007. At the regional level, business environment realizes that the country's regional economic power has deteriorated..$^{75}$ The danger of Kenya losing its status as the hub for the landlocked countries ${ }^{76}$ does not seem credible in the near future, considering the central corridor's lack of competitiveness, but in a more faraway future it is possible that the power relations change. All depends of the capacity of Kenya's partners (Uganda, Tanzania, Rwanda and Burundi) to weigh in regional and international institutions to clear the necessary funding for the modernization of the port of Dar are Salaam.

\section{BIBLIOGRAPHY}

BUSINESS MONITOR INTERNATIONAL (2007). 'Business forecast report for Tanzania.'

INTERNATIONAL CRISIS GROUP (2008). 'Kenya in crisis.' Africa Report no. 137, 21 February.

PORHEL, R. (2004). 'Infrastructures et développement, le cas de l'EAC.' Les Cahiers d'Afrique de l'Est, IFRA, no. 23, January-March.

SOCIETY FOR INTERNATIONAL DEVELOPMENT (SID) (2004). Pulling Apart: Facts and Figures on Inequality in Kenya.

Press

The Daily Nation

The Standard 
The EastAfrican

The Monitor

Internet sites

http://www.worldbank.org

http://www.oecd.org/

\section{NOTES}

1. Kenya can depend on its performing agro-food industry in which big companies are involved. The country also has manufactured products and enjoys highly developed mass tourism.

2. Importing companies needed government approval to buy some foreign products.

3. From 1993 (with effect from 1995), the World Trade Organization (WTO) replaced the General Agreement on Tariffs and Trade (GATT).

4. The East African Community (Kenya, Tanzania, Uganda, and Rwanda and Burundi since 1 July 2007), which was formally relaunched on 15 January 2001 would like to go beyond the common market stage by stressing more on the coordination of regional policies, especially infrastructure, through institutional cooperation. The political crisis, which affected the member countries in various ways, is a test for this organization. Will it be able to use its weight to ensure continuity in trade and insist on necessary regional reforms to avoid such deadlocks in future? Its relative silence seemed not to demonstrate this ability in February in 2008.

5. The volume of GDP growth rate in Kenya was $1 \%$ in $1999,0.5 \%$ and $0.6 \%$ in 2001 (World Bank).

6. World Bank, 2007.

7. World Bank (2007).

8. Kaldor's magic square includes the four objectives of conjunctural policy, which is GDP, inflation, employment and external balance.

9. Government of Kenya, Economic Survey, Nairobi, Government Printers, 2003.

10. Quadrupled deficit was observed between 2005 and 2006. However, at the beginning of M. Kibaki's term this deficit, without grants, had reached $9 \%$ of the GDP for the 2002/2003 financial year.

11. The rosy economic situation that Kenya had before the elections (growth attained $5.3 \%$ in volume for the 2006/2007 financial year) had not changed in any way the inequalities among its people. Kenya is among the group of ten countries on earth where social disparities are the worst, with incomes among the richest being 56 times higher than the incomes among the poorest, according to a United Nations report in 2004. 51.8\% of the people live under the poverty line (OCDE, 2006).

12. The HDI index includes GDP per capita, the literacy rates and life expectancy. From $0.56 \%$ in 1990 , it was $0.53 \%$ in 2006 and with wide gaps, in Nairobi (0.75 which is the medium level in Turkey), in Mombasa (0.65, the South African level) and in north and western parts of the country in Busia and Turkana (0.32, the level in Mali and Niger). 
Recent efforts in the education sector in Kenya should, however, improve this in the medium term.

13. World Bank classification: Countries with low revenue below 765 dollars in 1995; countries with medium revenue between 765 and 9,386 dollars in 1995; countries with high revenue above 9,386 in 1995.

14. World Bank, 2006.

15. Business Daily, 28 January 2008.

16. To the tune of 770 million dollars.

17. Central Bank of Kenya, 2007.

18. 900 million dollars in 2006, the first source of foreign exchange for country (French Ministry of Foreign Affairs).

19. On 7 August 1998, two simultaneous attacks rocked US embassies in Nairobi and Dar es Salaam (Tanzania), killing 224 people and injuring several hundreds of people. On 28 November 2002, a suicide attack on a hotel in Mombasa caused 18 deaths. A rocket attack on an Israeli airline aircraft shortly after managed to plunge Kenyan tourism to its darkest period.

20. The country has the highest concentration of banks in the region: 45 commercial banks make up the banking sector (Barclay Bank, Standard Chartered Bank), State banks (Kenya Commercial Bank, National Bank of Kenya), family banks (Kantaria) complemented by a number of non-banking institutions. There are also 95 foreign exchange bureaux.

21. The country two large companies are Safaricom and Celtel Kenya. They have managed to take advantage of infrastructural obsoleteness of fixed telephone service by State-owned Telkom Kenya to highly develop themselves, starting with one million subscribers in 2002 and increasing them to nearly eight million in 2007.

22. Improvement of the GPRS and EDGE networks by Safaricom and Celtel operators is ongoing. The extension of the the $3 \mathrm{G}$ networks and fibre optics is also ongoing (Kenya Data Networks).

23. Inter-Government Authority on Development.

24. An organization that is supposed to promote regional intergration through trade and investment in southern and eastern Africa. The member countries are Burundi, Comoros, the Democratic Republic of Congo, Djibouti, Egypt, Eritrea, Kenya, Madagascar, Malawi, Mauritius, Uganda, Rwanda, Seychelles, Sudan, Swaziland, Zimbabwe, Zambia and Libya.

25. Oil products, companies' capital assets, consumer products.

26. World Bank, 2007. Exports to Uganda increased in 2007 to 656 million dollars, 80\% of this are re-exported oil products; at the same time, exports to Rwanda increased to 112.5 million dollars.

27. Refer to R. Porhel, 2004.

28. Daily Nation, 11 January 2008. Three supermarkets, two petrol stations, restaurants and small traders' stalls were destroyed. The estimation of the losses during the firts five days was 44 million dollars but the cost rose rapidly. The "Kisumu City Business Disrtict Association" even considered that twenty years would be the sufficient time to recover from the loss. Even though it is an exagerration, this figure can give us an idea of the scale of the damage. 
29. Daily Nation, 3 January 2008.

30. An input is a product used in the manufacture of other products.

31. CNN, 11 January 2008. The big losers were: East African Breweries, Barclays, Kenya Commercial Bank, Ken Gen, Equity Bank, Mumias.

32. Daily Nation, 11 January, 2008.

33. The fact that the Diaspora continues to transfer capital is aid that cannot be ignored in maintaining the value of money on the market. Business Sunday Nation, 25 February 2008.

34. The rate for 91 days and 184 days were $6.86 \%$ and $7.84 \%$ respectively on 9 December and they rose to 7.33 and 8.35 on 17 February.

35. The rating is the ranking of countries according to risk and give information for investors.

36. AFP, January 2008.

37. Among the members of this group are namely Boeing, Cargill, Cisco, Exxon Mobil, General Motors, Coca Cola and even Starbucks.

38. Daily Nation, 15 January 2008.

39. 'Conflict Threatens Kenya Tourism.' Mc Clatchy News Services, 19 January 2008.

40. Daily Nation, 15 January 2008.

41. The East African, 28 January 2008.

42. Statement at the Berlin tourism exhibition by Achim Steiner, executive director of UNEP (United Nations Environment Programme), 7 March 2008.

43. In Morocco, the 2003 attacks on a hotel and restaurants patronized by foreigners and Jewish establishments in the city of Casablanca caused 45 deaths, including 12 suicide bombers. Yet Moroccan tourism experienced a boom during the first ten months of 2004, with $17 \%$ rise compared to the same period the previous year. In Egypt, an attack was carried out in October 2004 on Taba along the border with Israel, hitting Hilton Hotel, which was mainly occupied by Israelis, leading to the death of 30 people. Despte the attack the sector realized a spectacular growth of $34 \%$ the same year.

44. Daily Nation, 20 March 2008.

45. Unilever Tea suffered from $11 \%$ drop in production respresenting a loss of KSh 30 million, accompanied by a slump in the value of its stocks.

46. 'Political unrest sparks food insecurity, livehood losses.' Food Security in Kenya-IRIN News, 14 January 2008. URL: http://www.thenewhumanitarian.org/report/76221/ kenya-political-unrest-sparks-food-insecurity-livelihood-losses [archive].

47. 'Kenya faces famine threat.' Daily Nation, 23 January 2008.

48. Tea auctions were interrupted as a large part of the production came from the Rift Valley. Consequently, the $10 \%$ reduction in Kenya production caused an increase in the prices, according to FAO (Food and Agriculture Organization).

49. According to Richard Fox of Homegrown Limited Corporate Responsibility, $80 \%$ of the workers continued working.

50. Naivasha town suddenly went up in flames on 27 January when groups of Kikuyu youth in support of President M. Kibaki began attacking members of the opposition leader R. Odinga's ethnic community. Ten people who attempted to escape from the Kikuyu attackers were burnt alive in a block of houses. 
51. The loses were worth 10 billion shillings, according to Jane Ngigi, director of the Kenya Flower Council.

52. 'Tea sector limps on as workers trickle back.' The East African, 14 January 2008.

53. The Standard, 29 January 2008.

54. 'Kenya flower buyers get jitters despite continuing supply.' The East African, 28 January 2008.

55. Many companies applied for re-scheduling or the cancellation of the interests for this period. Business Sunday Nation, 18 February 2008.

56. Samuel Deya is the executive director of the Adock Timo, one of the main microfinance institutions in Kenya.

57. Business Sunday Nation, 18 February 2008.

58. Business Sunday Nation, 18 February 2008.

59. Kenya's Business Community, January 2008.

60. International Crisis Group: Kenya in crisis, op.cit.

61. Daily Nation, 14 January 2008.

62. The Monitor, 14 January 2008.

63. Kenya is the transit point for a quarter of Rwanda's and Uganda's GNP, a third of Burundi's GNP.

64. From 1.34 to 3.36 dollars. The Monitor, 9 January 2008.

65. 'Kenya tourism, economy devastated by violence' , CNN, 11 January 2008.

66. Northern Corridor: Mombasa-Kampala via Nairobi and Eldoret.

67. Daily Nation online, Business Daily, 9 February 2008.

68. 500 dollars per lorry on Mombasa-Malaba/Busia road and 254 dollars between Mombasa and Nairobi. Traffic returned to normalcy very slowly. Malaba recorded a resumption of its daily transactions in mid-February compared to January, rising from 100 to 250. Busia recovered even slower with 150 transactions from 100 . The country's business quarters estimated three months for a definite return to fluid traffic, which is the same as the time needed to decongest the Mombasa port.

69. Report by the Uganda Revenue Authority. The EastAfrican, 18 February 2008.

70. 'Business forecast Report for Tanzania' by Business Monitor International, 2007.

71. The East African, 12 March 2008.

72. Central Corridor: Dar es Salaam-Mwanza-Port Bell-Kampala ; Porhel, R. (2004).

73. Hub: A place which collects and redistributes goods and travellers to various directions from a transport network dominated by an airport. This is the case of Nairobi in which a network of tarmacked roads, railways and pipelines converge.

74. 'Business Forecast Report for Tanzania.' Business Monitor International, 2007.

75. Patrick Obath is the chairman of the federation of Kenyan employers.

76. Terry Ryan, economist at the University of Nairobi. News Voacom, 11 February 2008. 


\section{AUTHOR}

RONAN PORHEL

The author is a PHD holder in economics and research fellow at CREPAO (Centre for Studies and Research on East African Countries - Centre d'Étude et de Recherche sur les Pays d'Afrique Orientale, Université de Pau et des pays de l'Adour). 